Perspective

\title{
Research priorities for freshwater mussel conservation assessment
}

Noé Ferreira-Rodríguez ${ }^{\mathrm{a}, *}$, Yoshihiro B. Akiyama ${ }^{\mathrm{b}}$, Olga V. Aksenova ${ }^{\mathrm{c}}$, Rafael Araujo ${ }^{\mathrm{d}}$, M. Christopher Barnhart ${ }^{\mathrm{e}}$, Yulia V. Bespalaya ${ }^{\mathrm{c}}$, Arthur E. Bogan ${ }^{\mathrm{f}}$, Ivan N. Bolotov ${ }^{\mathrm{g}}$, Prem B. Budha ${ }^{\mathrm{h}}$, Cristhian Clavijo ${ }^{\mathrm{i}}$, Susan J. Clearwater ${ }^{\mathrm{j}}$, Gustavo Darrigran ${ }^{\mathrm{k}}$, Van Tu Do ${ }^{1}$, Karel Douda $^{\mathrm{m}}$, Elsa Froufe ${ }^{\mathrm{n}}$, Clemens Gumpinger ${ }^{\mathrm{o}}$, Lennart Henrikson ${ }^{\mathrm{p}}$, Chris L. Humphrey ${ }^{\mathrm{q}}$, Nathan A. Johnson ${ }^{r}$, Olga Klishkos, Michael W. Klunzinger, ${ }^{\mathrm{t}, \mathrm{v}}$, Satit Kovitvadhi ${ }^{\mathrm{w}}$, Uthaiwan Kovitvadhi ${ }^{\mathrm{x}}$, Jasna Lajtner ${ }^{\mathrm{y}}$, Manuel Lopes-Lima ${ }^{\mathrm{z}}$, Evelyn A. Moorkens ${ }^{\mathrm{aa}}$, Shigeya Nagayama ${ }^{a b}$, Karl-Otto Nagel ${ }^{\text {ac }}$, Mitsunori Nakano ${ }^{\text {ad,ae }}$, Junjiro N. Negishi ${ }^{\text {af }}$, Paz Ondina ${ }^{a g}$, Panu Oulasvirta ${ }^{\text {ah }}$, Vincent Priée ${ }^{a i}$, Nicoletta Riccardi $^{\text {aj }}$, Mudīte Rudzīte ${ }^{\text {ak }}$, Fran Sheldon $^{\text {al }}$, Ronaldo Sousa ${ }^{\text {,am }}$, David L. Strayer ${ }^{\text {an,ao }}$, Motoi Takeuchi ${ }^{\text {ap }}$, Jouni Taskinen ${ }^{\text {aq }}$, Amilcar Teixeira $^{\text {ar }}$, Jeremy S. Tiemann ${ }^{\text {as }}$, Maria Urbańska ${ }^{\text {at }}$, Simone Varandas ${ }^{\text {au }}$, Maxim V. Vinarski $^{\text {av }}$, Barry J. Wicklow ${ }^{\text {aw }}$, Tadeusz Zając ${ }^{\text {ax }}$, Caryn C. Vaughn ${ }^{\text {ay }}$

${ }^{a}$ Departamento de Ecoloxía e Bioloxía Animal, Universidade de Vigo, Lagoas Marcosende s/n., 36310 Vigo, Spain

b Coastal, Marine and Disaster Prevention Department, National Institute for Land and Infrastructure Management, 3-1-1, Nagase, Yokosuka, Kanagawa, Japan

${ }^{\mathrm{c}}$ N. Laverov Federal Center for Integrated Arctic Research, Russian Academy of Sciences, Severnaya Dvina Emb. 23, 163000 Arkhangelsk, Russia

${ }^{\mathrm{d}}$ Museo Nacional de Ciencias Naturales - C.S.I.C, José Gutiérrez Abascal 2, 28006 Madrid, Spain

e Department of Biology, Missouri State University, 901 S. National Ave., Springfield, MO 65897, USA

${ }^{\mathrm{f}}$ NC Museum of Natural Sciences, 11 West Jones St. Raleigh, NC 27601, USA

${ }^{\mathrm{g}}$ Northern Arctic Federal University, Severnaya Dvina Emb. 17, 163002 Arkhangelsk, Russia

${ }^{\mathrm{h}}$ Central Department of Zoology, Tribhuvan University, Kirtipur, Kathmandu, Nepal

${ }^{i}$ Museo Nacional de Historia Natural, 25 de mayo 582 - CC. 399, 11000, Montevideo, Uruguay

${ }^{\mathrm{j}}$ National Institute of Water and Atmospheric Research (NIWA), Gate 10 Silverdale Road, P.O. Box 11115, Hamilton, New Zealand

${ }^{\mathrm{k}}$ División Zoología Invertebrados, Museo de La Plata, Facultad de Ciencias Naturales y Museo (UNLP), CONICET, Paseo del Bosque s/n., La Plata 1900, Argentina

${ }^{1}$ Institute of Ecology and Biological Resources (IEBR), Vietnam Academy of Science and Technology, 18 Hoang Quoc Viet, Cau Giay, Ha Noi, Viet Nam

${ }^{\mathrm{m}}$ Department of Zoology and Fisheries, Faculty of Agrobiology, Food and Natural Resources, Czech University of Life Science Prague, CZ-16521 Prague, 6-Suchdol, Czech Republic

${ }^{n}$ CIIMAR - Interdisciplinary Centre of Marine and Environmental Research of the University of Porto, Terminal de Cruzeiros do Porto de Leixões, Avenida General Norton de Matos, S/N, 4450-208 Matosinhos, Portugal

${ }^{\circ}$ Consultants in Aquatic Ecology and Engineering (Technisches Büro für Gewässerökologie) - blattfisch e.U., Gabelsbergerstraße 7, 4600 Wels, Austria

${ }^{\mathrm{p}}$ Nature and Man Ltd (Natur och Människa AB), Friared Prästgården 3, 51198 Hyssna, Sweden

${ }^{\mathrm{q}}$ Supervising Scientist Branch, Department of the Environment and Energy, GPO Box 461, Darwin, NT 0801, Australia

${ }^{\mathrm{r}}$ U.S. Geological Survey Wetland and Aquatic Research Center, 7920 NW. 71st Street, Gainesville, FL 32653, USA

${ }^{\mathrm{s}}$ Institute of Natural Resources, Ecology and Cryology, Siberian Branch of Russian Academy of Sciences, 16a, Nedorezova str., 672014 Chita, Russia

${ }^{\mathrm{t}}$ BWG Environmental, Brisbane, QLD 4509, Australia

${ }^{\mathrm{u}}$ Murdoch University, School of Veterinary and Life Sciences, Perth, W.A. 6105, Australia

${ }^{\mathrm{v}}$ Western Australian Museum, Department of Aquatic Zoology, Welshpool, W.A. 6106, Australia

${ }^{\mathrm{w}}$ Department of Agriculture, Faculty of Science and Technology, Bansomdejchaopraya Rajabhat University, Bangkok 10600, Thailand

${ }^{\mathrm{x}}$ Department of Zoology, Faculty of Science, Kasetsart University, Bangkok 10900, Thailand

${ }^{\mathrm{y}}$ Division of Zoology, Department of Biology, Faculty of Science, University of Zagreb, Rooseveltov trg 6, 10000 Zagreb, Croatia

${ }^{\mathrm{z}}$ CIBIO/InBIO - Research Center in Biodiversity and Genetic Resources, University of Porto, Campus Agrário de Vairão, Padre Armando Quintas, $4485-661$ Vairão, Portugal

${ }^{\text {aa }}$ University of Dublin, Trinity College, Dublin 2, Ireland

${ }^{\text {ab }}$ River Basin Research Center, Gifu University, 1-1 Yanagido, Gifu, Japan

${ }^{\text {ac }}$ Senckenberg Forschungsinstitut und Naturmuseum Frankfurt, Abteilung Marine Zoologie/Sektion Malakologie, Senckenberganlage 25, 60325 Frankfurt/Main, Germany

${ }^{\text {ad }}$ Faculty of Bioresources and Environmental Sciences, Ishikawa Prefectural University, 1-308 Suematsu, Nonoichi, Ishikawa 921-8836, Japan

ae The Japan Association of Rural Solutions for Environmental Conservation and Resource Recycling, 5-34-4 Shinbashi, Minato, Tokyo 105-0004, Japan

${ }^{\text {af }}$ Faculty of Environmental Earth Science, Hokkaido University, N10W5, Sapporo, Hokkaido 060-0810, Japan

${ }^{\mathrm{ag}}$ Departamento de Zooloxía, Xenética e Antropoloxía Física, Facultade de Veterinaria, Universidade de Santiago de Compostela (USC), Avda. Carballo Calero s/n., 27002 Lugo, Spain

${ }^{\text {ah }}$ Alleco Ltd., Veneentekijäntie 4, 00210 Helsinki, Finland

\footnotetext{
* Corresponding author at: Department of Ecology and Animal Biology, Faculty of Biology, University of Vigo, Lagoas Marcosende s/n., 36310 Vigo, Spain. E-mail address: noeferreira@uvigo.es (N. Ferreira-Rodríguez).
} 
${ }^{\text {ai } I n s t i t u t ~ S y s t e ́ m a t i q u e ~ E ́ v o l u t i o n ~ B i o d i v e r s i t e ́ ~(I S Y E B), ~ M u s e ́ u m ~ n a t i o n a l ~ d ' H i s t o i r e ~ n a t u r e l l e, ~ C N R S, ~ S o r b o n n e ~ U n i v e r s i t e ́, ~ E P H E, ~} 57$ rue Cuvier, CP 26, 75005 Paris, France

${ }^{\text {aj }}$ CNR IRSA - Water Research Institute, Largo Vittorio Tonolli, 50-52-28922 Pallanza Verbania, Italy

${ }^{\mathrm{ak}}$ Museum of the University of Latvia, Raina Blvd. 19, Riga LV-1586, Latvia

${ }^{\text {al }}$ Australian Rivers Institute, Griffith University, 170 Kessels Road, Nathan, QLD 4111, Australia

${ }^{a m}$ CBMA - Centre of Molecular and Environmental Biology, Department of Biology, University of Minho, Campus de Gualtar, 4710-057, Braga, Portugal

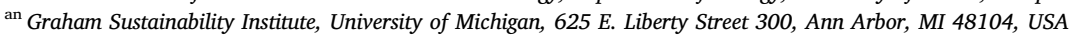

${ }^{\text {ao }}$ Cary Institute of Ecosystem Studies, P.O. Box AB, Millbrook, NY 12545, USA

${ }^{\text {ap }}$ Prefectural Kuji High School, 1-15 Osanai School, kawasaski, Kuji, Iwate 028-0051, Japan

${ }^{\mathrm{aq}}$ Department of Biological and Environmental Science, PO Box 35, FI-40014, University of Jyväskylä, Finland

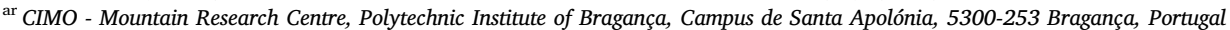

as Illinois Natural History Survey, University of Illinois at Urbana-Champaign, 1816 S. Oak Street, Champaign, IL 61820, USA

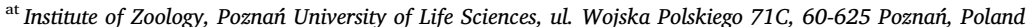

${ }^{\text {au }}$ CITAB - Centre for Research and Technology of Agro-Environment and Biological Sciences, Forestry Department, University of Trás-os-Montes and Alto Douro, 5000-801

Vila Real, Portugal

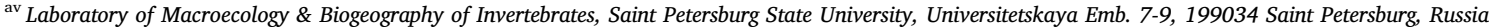

${ }^{\text {aw }}$ Department of Biology, Saint Anselm College, 100 Saint Anselm Drive, Manchester, NH 03102, USA

${ }^{a x}$ Institute of Nature Conservation, Polish Academy of Sciences, Mickiewicza, 33, 31-120 Kraków, Poland

ay Oklahoma Biological Survey, Ecology and Evolutionary Biology Graduate Program, Department of Biology, University of Oklahoma, 111 E. Chesapeake Street, Norman, OK 73019, USA.

\section{A R T I C L E I N F O}

\section{Keywords:}

Unionida

Intrinsic factors

Extrinsic factors

Indicators

Threats

Management

\begin{abstract}
A B S T R A C T
Freshwater mussels are declining globally, and effective conservation requires prioritizing research and actions to identify and mitigate threats impacting mussel species. Conservation priorities vary widely, ranging from preventing imminent extinction to maintaining abundant populations. Here, we develop a portfolio of priority research topics for freshwater mussel conservation assessment. To address these topics, we group research priorities into two categories: intrinsic or extrinsic factors. Intrinsic factors are indicators of organismal or population status, while extrinsic factors encompass environmental variables and threats. An understanding of intrinsic factors is useful in monitoring, and of extrinsic factors are important to understand ongoing and potential impacts on conservation status. This dual approach can guide conservation status assessments prior to the establishment of priority species and implementation of conservation management actions.
\end{abstract}

\section{Introduction}

Freshwater mussels (Mollusca: Bivalvia: Unionida) are benthic macroinvertebrates that use their muscular foot and shell to burrow into the sediment (Allen and Vaughn, 2009). Adults filter-feed on particles from the water column and interstitial space using cilia-generated water currents (Vaughn et al., 2008; Walker et al., 2014). They have a unique life cycle in which the larva (glochidia, lasidia, or haustoria) must attach to a vertebrate host, usually a fish, and subsequently metamorphose into a juvenile mussel (Wächtler et al., 2001).

Scientific interest in freshwater mussels has grown dramatically since the 1970s (Strayer et al., 2004; Lopes-Lima et al., 2014) when the first modern extinctions were recognized (Stansbery, 1970, 1971). As currently defined, the Order Unionida, the freshwater mussels, comprises six nominal families and around 800 described species, although the exact number fluctuates as new species are described and taxonomic revisions to existing taxa are made (Williams et al., 2017; Graf and Cummings, 2018). In this context, accurate taxonomic identification plays a key role in species conservation, and modern phylogenetic information is a critical component of conservation biology (Morrison III et al., 2009). Freshwater mussels are globally imperiled (6\% of known species having recently become extinct; IUCN, 2017), with declines in distribution and abundance related to a variety of factors including habitat modification, water quality degradation, climate change, introduction of non-native species, declines in fish hosts, and over-exploitation (Strayer et al., 2004; Walker et al., 2014; Lopes-Lima et al., 2018). Of 535 freshwater mussel species assessed by the International Union for Conservation of Nature (IUCN, 2017), 217 were categorized as Near Threatened, Vulnerable, Endangered, or Critically Endangered, and 89 species were classified as Data Deficient (Fig. 1). Given these high levels of imperilment, establishing research priorities that support more accurate determination of a species' status is critical. Here we summarize the most important research needs for assessing the conservation status of freshwater mussels (Table 1) and discuss how practitioners can leverage this information to improve the development and implementation of effective conservation and management strategies.

Characters used to assess the conservation status of a given group of organisms can be subdivided into intrinsic and extrinsic factors (following Williams et al., 2008; Dawson et al., 2011; Fig. 2). Intrinsic factors are measures of a species' condition and provide valuable information about demographic trends (e.g., abundance, distribution, and viability of extant populations) and population health status (e.g.,

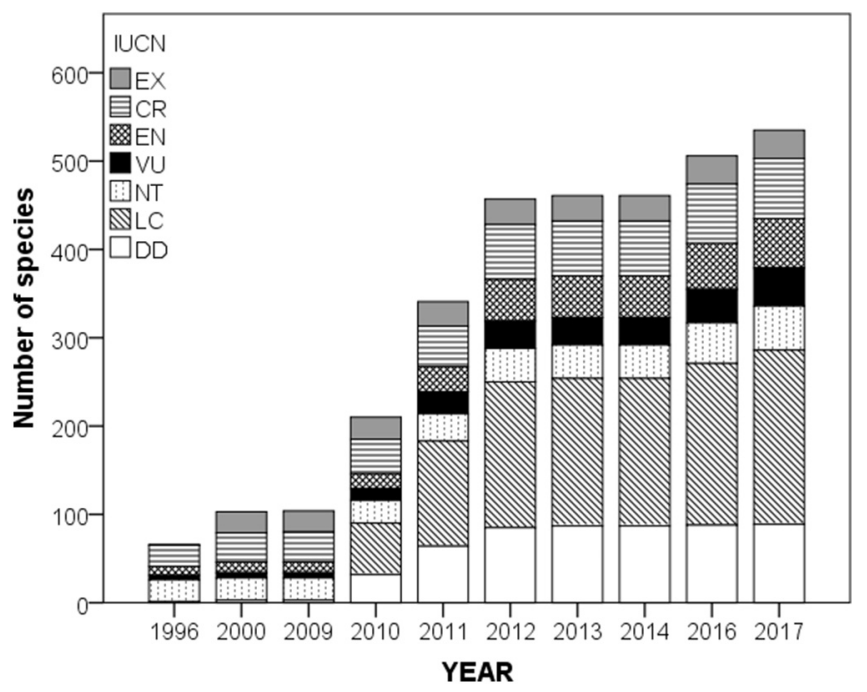

Fig. 1. Number of assessed freshwater mussel taxa and distribution of IUCN Red list status in recent years. DD, Data Deficient; LC, Least Concern; VU, Vulnerable; NT, Near Threatened; EN, Endangered; CR, Critically Endangered; EX, Extinct. (For interpretation of the references to colour in this figure legend, the reader is referred to the web version of this article.) 
Table 1

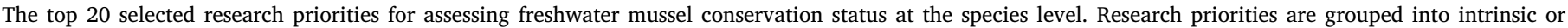
extrinsic factors. Intrinsic factors are measures of species condition, and extrinsic factors describe the state of the environment.

\begin{tabular}{|c|c|c|}
\hline Category & Factor & Research priority \\
\hline \multirow[t]{5}{*}{ Intrinsic } & Species identity & Perform accurate species identification and determine species boundaries \\
\hline & $\begin{array}{l}\text { Population size and species } \\
\text { distribution }\end{array}$ & Determine species' population size; and current species distribution \\
\hline & Population trends & Determine the historic distribution range and population size \\
\hline & Demography & $\begin{array}{l}\text { Assess population viability, and perform demographic studies (e.g., recruitment, population age structure, mortality rates, } \\
\text { immigration and emigration) }\end{array}$ \\
\hline & Life-history traits & $\begin{array}{l}\text { Identify traits and boundaries related to extinction risk, particularly characterize reproductive traits (reproductive strategy, } \\
\text { timing of the reproductive cycle, fecundity, lifespan, age at sexual maturity, and generation length), and determine life } \\
\text { history traits }\end{array}$ \\
\hline \multirow[t]{8}{*}{ Extrinsic } & Fish hosts & $\begin{array}{l}\text { Identify primary mussel/host relationships, host histological compatibility (metamorphosis success), and host availability } \\
\text { (contact probability) }\end{array}$ \\
\hline & Habitat characteristics & Identify habitat characteristics (including climate and catchment characteristics) related to species presence \\
\hline & Catchment usage & Analyze species' response to land-use change (sedimentation, turbidity, nutrient pollution) \\
\hline & Habitat alteration & $\begin{array}{l}\text { Assess the impact of impoundments or other alterations on mussels (e.g., low oxygen concentration, increasing temperature, } \\
\text { stagnation), and assess the impact of impoundments or other alterations on fish host movements and accessibility }\end{array}$ \\
\hline & $\begin{array}{l}\text { Water quality and sediment } \\
\text { contamination }\end{array}$ & Assess ecotoxicological response of adult and early life stages (especially) to pollutants including novel contaminants \\
\hline & Climate change & $\begin{array}{l}\text { Determine the effect of increasing temperature at different organizational levels, determine the tolerance to emersion and } \\
\text { assess the effect of successive extreme climatic events (e.g., heat waves, floods) }\end{array}$ \\
\hline & Non-native bivalve species & $\begin{array}{l}\text { Assess the strength of competition at different life stages solely or in combination with other threats (e.g., climate change, } \\
\text { pollution) }\end{array}$ \\
\hline & Other extrinsic factors & Identify and assess whether secondary factors (listed in text) represent a global or a localized threat to species \\
\hline
\end{tabular}

\section{Extrinsic factors}

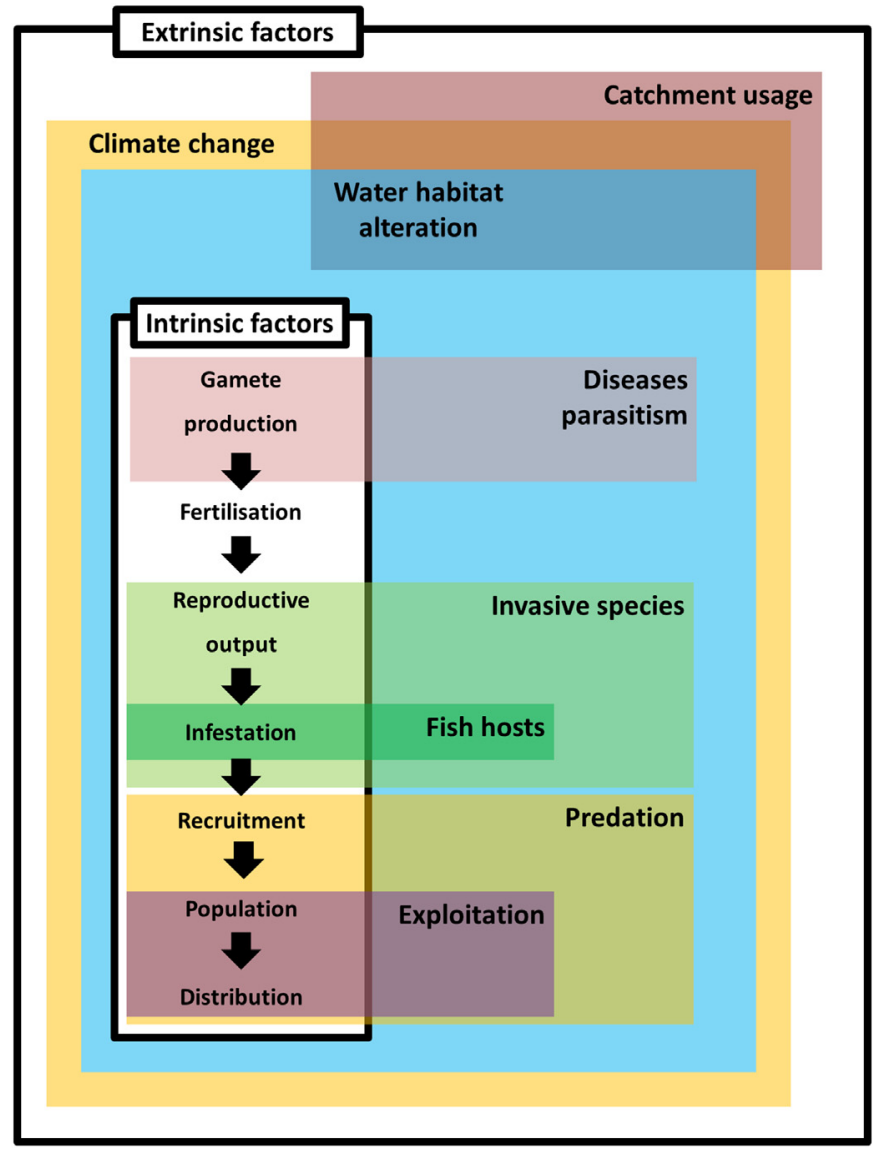

Fig. 2. General framework for assessing freshwater mussel conservation status. Intrinsic factors are measures of the species condition based on individual- and/ or population-level processes. Extrinsic factors describe the state of the environment. All elements of this framework need to be considered in a comprehensive species-level risk assessment.

reproduction, nutritional status, genetic variability, and growth). Extrinsic factors describe the state of the environment and include factors such as habitat condition and availability, water quality and quantity, impacts of invasive species, and flow alterations, among other ecologically-mediated threats.

Individuals respond to extrinsic factors through phenotypic plasticity, and populations respond through adaptation (Fisher, 1930). Phenotypic plasticity has limits, and the potential for evolutionary adaptation depends on genetic polymorphism within populations. Thus, for conservation of at-risk species, it is important to identify which intrinsic factors make these species vulnerable to environmental change (Fig. 3) to help guide conservation actions in a changing environment (e.g., habitat restoration). This includes adaptive genetic variation, which represents the basis for evolutionary change in the future, but is largely unexplored for freshwater mussels.

In this paper, we assess the research needed to guide conservation status assessments and future conservation actions for freshwater mussels by summarizing the knowledge of a multidisciplinary, global team of scientists working in this area. We divide research priorities into two categories. First, we discuss how an understanding of intrinsic factors can help us better assess changes in freshwater mussel

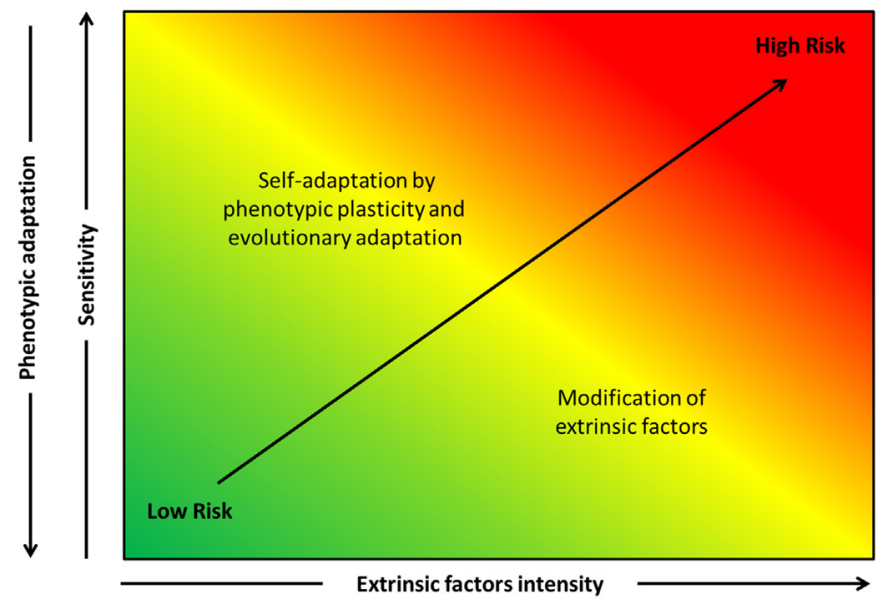

Fig. 3. Species risk assessment based on exposure to extrinsic factor and intrinsic sensitivity. The balance between the species intrinsic factors able to adapt to environmental change and extrinsic factor modifications determine the implementation of conservation and/or recovery plans. Adapted from Dawson et al. (2011). 
populations and species over space and time. Second, we identify extrinsic factors that can influence such changes. Lastly, we discuss some strategies to guide freshwater mussel protection, conservation and management.

\section{Intrinsic factors}

\subsection{Species identity}

Because actual conservation and policies and actions generally occur at the species level, accurate species identification and delimitation is critical. Historically, most taxonomic work has focused on Europe and North America, and even there some species are still being revised and new species are being described (Froufe et al., 2017; Williams et al., 2017; Smith et al., 2018; Pieri et al., 2018). However, freshwater mussels in Africa, Asia, Australasia, South and Central America have been understudied and merit much more attention (Walker et al., 2014; Zieritz et al., 2018). For example, almost every large or medium-sized tropical freshwater basin in Indo-China is a separate evolutionary hotspot harboring a unique endemic freshwater mussel fauna, and several new genera and species were recently described from this region (Bolotov et al., 2017a, 2017b). However, taxonomic revision of mussel species-level classification is complicated by centuries of "over-description". For example, there are more than 400 synonyms for Anodonta cygnea (Graf and Cummings, 2018). Further, the characters used to define species have been a persistent and contentious problem. Conchological characters traditionally used to identify taxonomic units can be phenotypically plastic and dependent on ecological conditions (Zieritz et al., 2010; Sheldon, 2017). In contrast, studies using molecular data and assessing genetic variability have suggested cryptic speciation where there is no clear morphological differentiation (e.g., Baker et al., 2003; Prié and Puillandre, 2014; Graf et al., 2015; Sheldon, 2017; Araujo et al., 2018; Pieri et al., 2018).

Species identity is often incompletely delimited and is a fundamental conservation priority. Morphology combined with molecular phylogenetic information focused on taxa of conservation concern can dramatically improve this situation (Smith et al., 2018). Application of mitochondrial and nuclear DNA markers, as well as next-generation sequencing technologies, and the application of phylogenetic species delimitation methods are promising approaches to improve our understanding of freshwater mussel diversity (Inoue et al., 2018; Smith et al., 2018).

\subsection{Population size and species distribution}

Rare or endangered species face genetic risks from small population or range sizes (e.g., genetic drift, inbreeding depression, self-fertilization, and low gene flow; Geist and Kuehn, 2005). In freshwater mussel conservation, much emphasis has been placed on the local abundance of a species, and little on the overall abundance of that species across its entire range and connections between local populations in a larger, regional metapopulation (Newton et al., 2008). Our knowledge about the spatial delimitation of metapopulations is scarce (Terui et al., 2014). Moreover, minimum viable population sizes vary among species, but there are no globally objective criteria used to establish a baseline (Nunney and Campbell, 1993) and there is little knowledge about which abundances are viable for most species. However, against this background it should be recognized that some species have always been rare or have always occupied a limited geographic area. In this regard, low abundance or a small distribution per se does not necessarily indicate imperilment (Geist, 2010; Geist et al., 2010). Nevertheless, species with small distributions are more vulnerable to localized human activities, and to environmental and demographic stochasticity.

Assessing population abundance based solely on field observations is costly and time-consuming, but can be done by trained volunteers or scientists. Molecular techniques offer options for complementing field- based observations, but should not be viewed as alternatives. Rather, molecular techniques can provide information complementary to field observations. Such molecular techniques (e.g., microsatellites; Froufe et al., 2016) require minimal effort to estimate many biological parameters of interest, including demographic parameters (e.g., abundance, occupancy, disease status), population genetic parameters (e.g., genetic diversity, structure, effective population size), and responses to selective pressures (e.g., exploitation, climate change) (reviewed by Schwartz et al., 2007). In addition, it is possible to use molecular markers to monitor and estimate the level of migration, invasion, and hybridization in wild populations (Koneva, 2013). The development of noninvasive sampling using environmental DNA (eDNA) is also promising, especially for detecting the presence of species under difficult sampling conditions (Sansom and Sassoubre, 2017).

\subsection{Species trends}

Trends in abundance or distribution are a central consideration in assigning a threat rankings to species. Species trends can be revealed by comparing current and historical data on population sizes and distributions (Bolotov et al., 2012). For example, in France, species distribution models were used to infer range contraction, comparing the extent of occurrence predicted by the models to the currently known extent of occurrence of seven freshwater mussel species (Prié et al., 2014). Popejoy et al. (2018) used zooarchaeological data to characterize freshwater mussel assemblage composition before European colonization of the American continent and compare it to recent mussel assemblages. Similarly, in Australia, initial attempts have been made to compare the species composition of Aboriginal middens with current populations to understand changes in species distributions (Garvey, 2017). Information from historic and contemporary museum collections and field observations can be used to determine spatiotemporal changes in species' ranges (e.g., Johnson et al., 2016; Randklev et al., 2018). Interviews with local people (i.e., "citizen scientists") also could provide important information about changes in the distribution and abundance of freshwater mussels over time.

Understanding the historic range of a species is critical in determining its temporal trend; however, estimating trends with precision can be difficult. The IUCN approach for determining the Green and Red Lists of threatened species is to examine changes in population size, areas of occupancy and changes in extents of occurrence over set time periods. These estimations also can be provided by using molecular methods such as Bayesian Skyline Plots (i.e., studies of DNA to estimate the genealogy and the relative timing and duration of past demographic events; Drummond et al., 2005), which have been rarely used in demographic studies of freshwater mussels (but see Jones et al., 2015).

\subsection{Demography}

Absence of recruitment is a major process driving freshwater mussel declines (e.g., Strayer and Malcom, 2012). The age structure of a mussel population reflects past recruitment events and can be used to project future population trends using conventional demographic modelling tools (e.g., life tables; Vandermeer and Goldberg, 2003). Except for extremely long-lived species, a prevalence of adult mussels with limited or no younger cohorts may mean that recruitment has declined or failed and that the species is under extinction threat (i.e., "extinction debt"; Haag, 2012).

Some long-lived mussel species can persist with infrequent and low recruitment events, even though juvenile survival can be quite low (e.g., Margaritifera auricularia; Prié et al., 2018). Other species require more frequent and even annual recruitment to maintain sustainable populations (Outeiro et al., 2008; Hastie et al., 2010; Klunzinger et al., 2014). Factors leading to low recruitment include juvenile habitat degradation and decreases in the populations of fish hosts (Bolotov et al., 2012). 
Demographic studies examining reproduction, recruitment, population age structure, sex ratios, mortality rates, immigration, and emigration within a metapopulation are of importance for early detection of decline, especially in threatened species (Haag, 2012). Determining demographic structure requires adequate sampling strategies (e.g., Lois et al., 2014) to locate different juvenile stages and determine spawning and recruitment patterns - seasonal or aseasonal.

\subsection{Life-history traits}

Many unionid species are long-lived (e.g., M. margaritifera can live up to 280 years; Lopes-Lima et al., 2017), with slow growth, late sexual maturity, and low recruitment compared to other groups of freshwater invertebrates (Haag, 2012). However, these life-history parameters can be highly variable within and among species. In this regard, reproductive timing is highly dependent on climate and other environmental factors. For instance, temperature influences the length of the larval development period, and local hydrology can determine larval release (e.g., Hughes et al., 2004; Strayer, 2008; Araujo and ÁlvarezCobelas, 2016; Bunn et al., 2006). An understanding of reproductive phenology and other life history traits can be used to predict local colonization, extinction patterns and provide insights into the long-term persistence of populations (Vaughn, 2012).

Reproductive traits that might be included as research priorities for assessing mussel conservation status include strategies for attracting fish hosts and releasing larvae (e.g., broadcast of free larvae, conglutinates, and mantle displays; Barnhart et al., 2008), the timing and length of different reproductive stages (gamete production, larval a

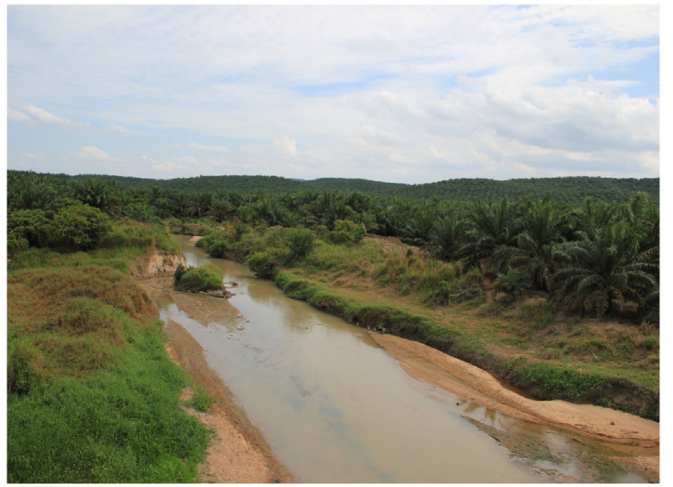

C

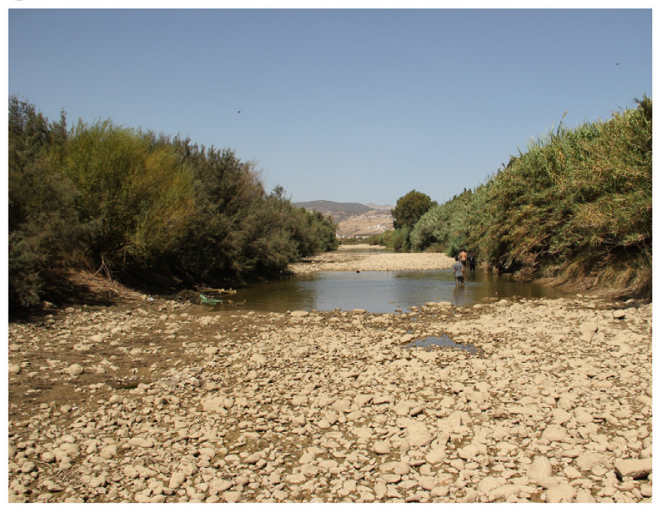

e

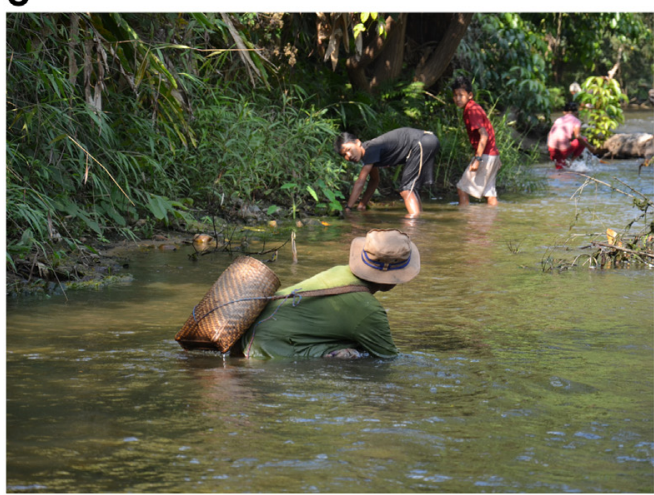

b

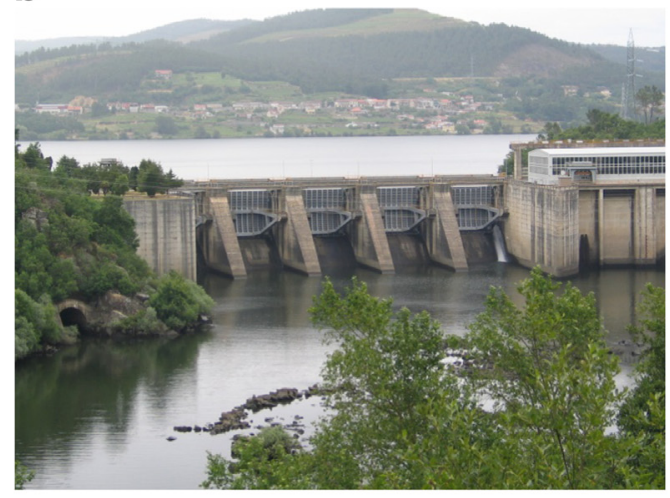

d

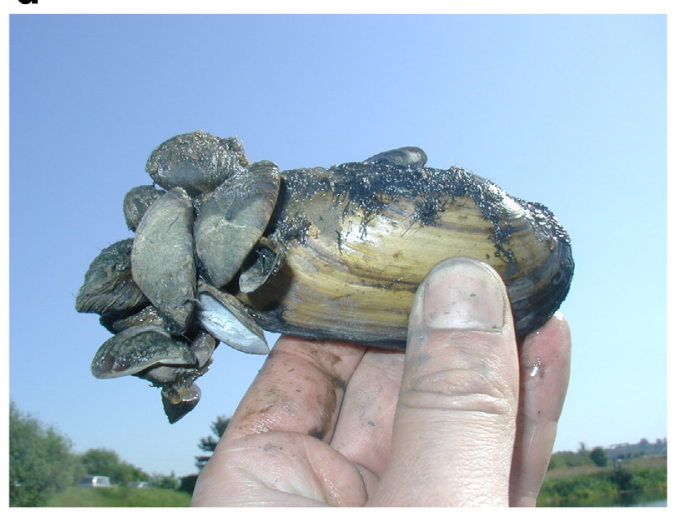

f

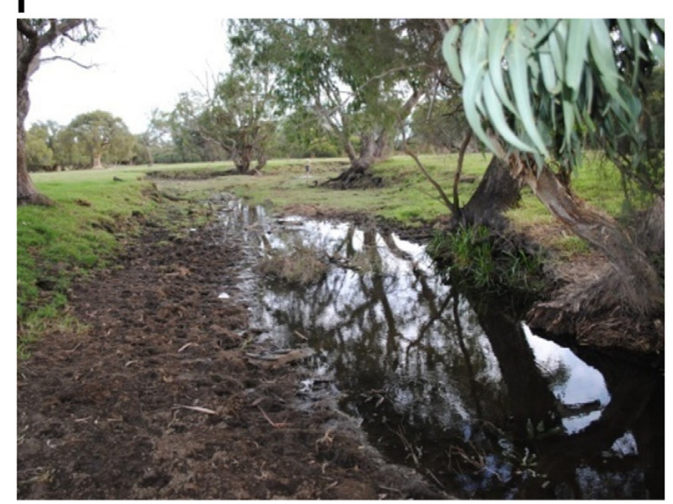

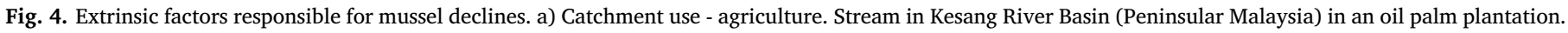

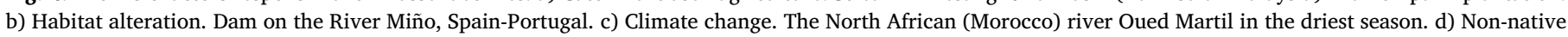

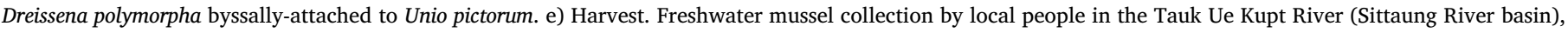
Myanmar. f) habitat destruction by cattle, Gingin Brook, southwest Australia. 
brooding, larval release), fecundity, lifespan, age at sexual maturity, and generation length (average age of parents of the current cohort). With this aim, non-destructive sampling methods such as monitoring free oocytes in ovarian follicles (Dudgeon and Morton, 1983) or examining marsupial brood development in live individuals (Reid et al., 2012) or examination of host fishes for mussel glochidia (Salonen and Taskinen, 2017) are recommended, especially in rare, endangered and long-lived species (Saha and Layzer, 2008).

\section{Extrinsic factors}

\subsection{Fish hosts}

Conservation of freshwater mussels requires understanding the status of their fish hosts and conserving them as well. Most unionid mussels have obligate ectoparasitic larvae which attach to the gills, fins or other body surfaces of their hosts (for exceptions, see Modesto et al., 2018). Accordingly, mussels must co-occur with appropriate vertebrate hosts to complete their life cycle and allow long-term survival of the population. In addition, movement of infested fish hosts is important to maintain connectivity among mussel metapopulations and upstream dispersal (Zając et al., 2018).

Factors related to larval dispersal ability, host attachment mode, and whether a mussel species is a host generalist or specialist, are key determinants of recruitment success or failure (Newton et al., 2008). In addition, detailed information on parameters such as infestation abundance (infested fish/total number of fish), infestation intensity (larvae/infested fish), host physiological compatibility (metamorphosis success) and host availability (contact probability) is fundamental (e.g., Salonen et al., 2017). This information can be acquired through laboratory experiments to determine fish hosts and subsequent field studies to verify that these relationships occur in nature (e.g., Klunzinger et al., 2012). Sampling fish assemblages to determine natural infestation rates and host population size, distribution and life history can be used to determine host availability and contact probability (Jansen, 1991; Kelly and Watters, 2010). Information on fish host population trends and movement can be used to determine the potential for mussel dispersal, which is important for long-term conservation; e.g., for founding new populations as habitat changes. In addition, many of the factors that affect fish hosts (e.g., habitat degradation, water quality impairment or invasive species) also affect mussel recruitment and can have cascading effects on the entire freshwater mussel assemblage (Geist et al., 2006; Stoeckl et al., 2015).

\subsection{Habitat characteristics}

Predicting suitable habitat and the potential distribution of freshwater mussel species is a high priority for conservation (Jones and Byrne, 2014). However, predicting freshwater mussel diversity hotspots differs from assessments for many other aquatic and terrestrial species because it is easier to locate a population than to predict its distribution, and is dependent on the characteristics of the whole catchment (Abell et al., 2006; Graf and Cummings, 2011).

An understanding of habitat requirements - leading to development of mussel species distribution models - can be based on field surveys, published information, historical data (including museum collections) on freshwater mussel presence, and local knowledge (Bolotov et al., 2012; Prié et al., 2014). Both natural and anthropogenic factors are important in modelling suitable habitat characteristics to predict species distributions (Mynsberge et al., 2009), including current and historical climates, catchment and stream characteristics, water and sediment characteristics, floral and faunal assemblages, and anthropogenic threats (Strayer, 1999; Howard and Cuffey, 2003; Geist and Auerswald, 2007; Inoue et al., 2015; Klunzinger et al., 2015). However, complete information is rarely available. In addition, in assessing historic sites, recent data on how habitats may have been modified or disturbed should be evaluated to understand which changes led suitable habitats to become unsuitable (e.g., Zieritz et al., 2018). Finally, scale differences and correlations among factors can complicate modelling. The use of high-resolution ecological niche modelling and computer models (e.g., GIS) coupled with field verifications can assist in this effort (Inoue et al., 2015; Walters et al., 2017).

\subsection{Catchment use}

Anthropogenic land-cover alteration is one of the biggest drivers of global change and profoundly affects biological diversity and ecosystem health (Dynesius and Nilsson, 1994; Allan, 2004). In general, land-use change (e.g., deforestation, agricultural development, livestock production, mining, and drainage of wetlands) (Fig. 4a) can increase erosion and pollution, and change river discharge regimes (Makhrov et al., 2014; Walker et al., 2014), all likely to have impacts on freshwater mussel populations.

Deposited and suspended materials impact mussels in two ways: by clogging mussel gills and thereby interfering with filter feeding, and by filling interstitial spaces in substrates and thereby eliminating important habitats for juveniles (Österling et al., 2010; and references therein). Wicklow et al. (2017) found that riparian forest cover was a strong predictor of healthy populations of the imperiled brook floater, Alasmidonta varicosa, whereas low or no forest cover was associated with the most vulnerable populations. In Southeast Asia, declines in the endemic mussel fauna appear to be related to deforestation and agriculture (Bolotov et al., 2014; Zieritz et al., 2018). In contrast, agricultural drainages from paddy fields in Japan positively affect mussels living in rivers and agricultural ditches due to increased food abundance and more suitable water temperatures (Nakano, 2017; Nishio et al., 2017). Hence, assessment of the degree of a species' tolerance to impacts associated with land-use change (e.g., sedimentation, turbidity, nutrient pollution) is of paramount importance for predicting the present and future impacts on freshwater mussel assemblages (Gallardo et al., 2018).

\subsection{Habitat alteration}

Altered flow (hydrological) and temperature regimes associated with impoundment are one of the most important threats to freshwater fauna generally (Fig. 4b). Impoundments alter seasonal temperature regimes and create lentic or semi-lentic conditions with higher sedimentation and low oxygen concentrations. Therefore, species composition may shift, with reductions in the abundance of riverine taxa and increases in lentic taxa (Pringle et al., 2000). At the same time, releases from reservoirs can alter flow regimes which may increase the probability of mortality of mussels (e.g., by exposure to thermal variations; Gagnon et al., 2004; Haag and Warren, 2008; Araujo and ÁlvarezCobelas, 2016). Furthermore, hypolimnetic dam discharge may negatively affect gametogenesis and glochidial production (Haag, 2012). Structures such as dams, floodgates and hanging culverts can also block the movement or alter the species assemblages of fish hosts (Tiemann et al., 2004; Winemiller et al., 2016), making them less available to mussels, isolating populations, and impacting mussel reproductive success and contributing to overall assemblage depletion (Smith, 1985; Watters, 1996; Kelner and Sietman, 2000; Vaughn, 2012). In extreme cases, mussels have been completely isolated from their fish hosts, resulting in functional extirpation, such as with Ebonyshell, Reginaia ebenus, in the Upper Mississippi River (Kelner and Sietman, 2000).

Given the unprecedented boom in construction of hydropower dams in South America, Africa and Asia (Winemiller et al., 2016), studies are needed to assess the effects of such habitat alterations on mussels and their fish hosts. Such studies need to assess both individual, cumulative, and interactive impacts of multiple stressors (e.g., low oxygen, increasing or decreasing temperature, flow velocity). In addition, other 
hydrological and habitat alterations likely to affect freshwater mussels include sand and gravel extraction, channelization, riverine urbanization, and cattle access to rivers.

\subsection{Pollution}

Water and sediment pollution from point sources (e.g., chemical or quarry spills, urban or industrial wastewater discharge) and non-point sources (e.g., runoff from agriculture and roads) influences mussels (Grabarkiewicz and Davis, 2008; Gillis et al., 2017). Unionid mussels are generally underrepresented in toxicity databases used for developing of protective water quality criteria and other guidance. When compared with other freshwater organisms, mussel species were among the species most sensitive to a variety of chemical compounds (Wang et al., 2017), with juvenile life stages particularly sensitive to water and sediment pollution (Augspurger et al., 2003; Cope et al., 2008; Taskinen et al., 2011; Wang et al., 2017; Kleinhenz et al., 2018).

Most toxicity tests have traditionally used survival as the endpoint (Naimo, 1995), and more attention to sublethal effects on physiology and reproduction is needed. As an example, molecular approaches (i.e., gene expression) recently performed in freshwater mussels allow the identification of differentially expressed genes in response to environmental stressors (Michalak et al., 2017; Ferreira-Rodríguez et al., 2018a). In addition to laboratory tests, we need to understand pollution - including micropollutant - effects on ecological condition and demography. This will require extensive testing to include sediment- and diet-borne contaminant exposures (Cope et al., 2008), multiple stressors, field monitoring, and in situ experiments to establish ecological thresholds and translate these into enforceable water quality regulations.

\subsection{Climate change}

Climate change threatens freshwater mussels through higher temperatures, and increased frequency and severity of droughts and floods (Kundzewicz et al., 2008; Fig. 4c). The thermal regime of their aquatic habitat is related to larval metamorphosis success (Taeubert et al., 2014), metabolic rate (Ferreira-Rodríguez and Pardo, 2017), and overall survival (Akiyama and Iwakuma, 2007; Pandolfo et al., 2010). Temperature stress also can affect the sensitivity of mussels to additional stressors, such as hypoxia, water pollution or introduction of nonnative species (van Hattum et al., 1993; Ferreira-Rodríguez and Pardo, 2017). Additionally, severe droughts associated with extreme temperatures can result in extremely low flows, with declines in species richness and local extirpations (Gagnon et al., 2004; Haag and Warren Jr., 2008; Sousa et al., 2018). In contrast, flooding due to extreme precipitation events can scour mussel beds, disrupt recruitment, or hinder species recovery efforts, such as translocations or reintroductions of endangered species (Strayer, 1999; Steuer et al., 2008; Haag, 2012; Stodola et al., 2017).

The effects of climate change may be exacerbated by increased anthropogenic water withdrawals and river regulation for human needs (Carter et al., 2014; Prein et al., 2016). Moreover, shortened intervals between successive extreme climatic events may not allow sufficient time for freshwater mussel assemblages to recover demographically, particularly for long-lived, low-recruitment species (Vaughn et al., 2015). A combination of modelling and experimental approaches is needed to predict how these changes will restructure mussel assemblages (Santos et al., 2015; Vaughn et al., 2015; Ferreira-Rodríguez and Pardo, 2017).

\subsection{Non-native bivalve species}

Biological invasions are also a major component of human-caused global change (Lockwood et al., 2013). The golden mussel Limnoperna fortunei in South America and Japan and zebra mussels Dreissena spp. in the Northern Hemisphere modify the nature and complexity of the substrate, abundance of plankton and other available food resources, which may negatively affect other freshwater mussels (Darrigran and Damborenea, 2005; Sousa et al., 2014; Fig. 4d). In addition, mussels byssally-attached to unionid shells may hamper their filter feeding, respiration, locomotion, and reproduction capacity by interfering with valve-movement behavior (Lucy et al., 2014). The Asian clam Corbicula spp. potentially competes for food and space with freshwater mussels (Ferreira-Rodríguez et al., 2018b). While reproduction of native freshwater mussel species may be constrained by fish immunity, host availability does not constitute a major limit for the Chinese pond mussel Sinanodonta woodiana, a broad generalist species (Douda et al., 2017). In addition, in a global warming context, some non-native species cope much better with unfavorable conditions (e.g., thermal extremes) than native species (Bielen et al., 2016). More work is needed to understand how non-native bivalves interact with and affect native mussels over the long term, including impacts on early life stages, to identify which native species can compete successfully with invaders, and to determine which species will face extinction by the additive effect of non-native competitors and other threats (e.g., climate change, pollution).

\subsection{Other extrinsic factors}

Other extrinsic factors influencing mussels include diseases and parasitism, exotic fish introductions, increased predation, and overexploitation. While these factors are often secondary in importance to habitat modification, land-use change, and water quality impairment can interact, becoming cumulative and locally important. Diseases and parasitism are potentially important, but few studies are available to assess their importance (Taskinen and Valtonen, 1995; Grizzle and Brunner, 2009; Carella et al., 2016). An increase in exotic fishes can impair reproduction of freshwater mussels (Taniguchi et al., 2002; Douda et al., 2014). Predation on mussels is usually size-selective upon smaller individuals, thereby affecting the age structure of populations (Tyrrell and Hornbach, 1998; Zając, 2014). Finally, freshwater mussel species may face local or even global extinction from human over-exploitation, particularly in Asia (Bolotov et al., 2014; Zieritz et al., 2018; Do et al., 2018; Fig. 4e). Hence, the incidence of these and other factors should be addressed when assessing the conservation status of the target species/population.

\section{Conservation and recovery plans}

The development of conservation strategies for freshwater mussels faces many challenges, including the selection of priority species and populations for conservation, strategic decisions about habitat restoration, captive propagation, and stakeholder and general public involvement (Geist, 2010; Strayer, 2017).

Laws and regulations to protect freshwater mussels have been enacted (although large differences exist between countries and continents), but very few protected areas have been established as refugia for endangered freshwater mussels (e.g., the Mudpuppy Conservation Area, Missouri, USA; reaches of the Verdigris, Fall, and Neosho Rivers in Kansas, USA). In the European Union, each member state hosting mussel species listed in Annex II of the Habitat's Directive has been required to protect important populations as Special Areas of Conservation (SAC's; Council Directive 92/43/EEC). However, the Habitats Directive was published in 1992 with knowledge from the 1980s, and it has not been updated since then. Therefore, the Directive does not reflect the correct number of threatened species, which leaves many taxa unprotected. In addition, external anthropogenic activities affecting freshwater mussels are also likely to affect population dynamics of fish hosts (Modesto et al., 2018); therefore, it is essential to delimit appropriate spatial scales of conservation units (Abell et al., 2006).

The conservation genetic literature describes two types of 
conservation units, evolutionary significant units and management units (Funk et al., 2012). An evolutionary significant unit (ESU) can be generally defined as a population or group of populations with high genetic and ecological distinctiveness from other units. Management units (MUs) are defined as populations that are demographically independent of one another (i.e., population dynamics depends on local birth and death rates and not on genetically effective migration). These principles are critical for conservation purposes in two respects. First, maintaining different ESUs will maximize evolutionary potential in the face of environmental change (Fraser and Bernatchez, 2001) and second, maintaining multiple MUs will help preserve demographic viability of infraspecific units and genetic diversity (Grobler et al., 2006; Zanatta and Harris, 2013). Although the use of neutral genetic markers is essential to diagnose evolutionary histories, further data (such as analysis of demographic trends and population-level evaluations of host compatibility) can be used to reveal ecologically relevant MUs.

To ensure the long-term persistence of species, a conservation strategy may include an approach to achieve ecologically sustainable land-use (protection from extrinsic factor modification; see Fig. 2), such as riparian vegetation buffers around waterways (e.g., Giam et al., 2015). However, caution must be exercised when restoration actions are proposed. For example, removing dams can harm freshwater mussels by releasing pollutants or destabilizing sediments. Fish passageways to allow migration past dams may be helpful in reconnecting upstream and downstream populations of both mussels and host fish (e.g., Benson et al., 2017). However, past designs often have been ineffective, and fish passageways sometimes are used to justify harmful dams (Brown et al., 2013). To prevent additional species losses - when the causes of decline are identified and corrected - researchers have developed methods for hatchery propagation of juvenile mussels to supplement, augment, or restore populations. Propagation programs will be critical for many recovery efforts (Carey et al., 2015). However, mussel propagation requires accurate genetic identification of conservation units prior to release of animals produced in hatcheries to ensure preservation of remaining genetic diversity (Jones et al., 2006; McMurray and Roe, 2017).

The involvement of local stakeholders, policy makers, local authorities, and others responsible for water management is a major challenge in achieving successful freshwater mussel conservation (e.g., Linehan, 2007). In addition, collaborative efforts will help to harness public interest and knowledge. Similarly, new information and communication technologies provide methods to improve popular discourse and knowledge portrayed in mass and social media about the importance of freshwater mussels (i.e., providing ecosystem services; Vaughn, 2018), thereby increasing social awareness of their values (Strayer, 2017). Certainly, closer cooperation between scientists is needed (e.g., the Freshwater Mollusk Conservation Society, U.S.A.), as well as initiatives such as adopting international standards for monitoring freshwater mussels (e.g., the M. margaritifera CEN Standard; British Standards Institution, 2017). Thanks to the knowledge gained through scientific research, techniques that enable the large-scale production of juveniles (including in vitro larval metamorphosis without fish hosts) are being developed and applied in recovery programs (e.g., Patterson et al., 2018). Finally, the quantifiable - temporal and spatial measurements that we have discussed here provide a synopsis of the conditions and trends of freshwater mussel populations and their habitats. However, without appropriate support and funding, effective conservation will be difficult to implement.

\section{Acknowledgments}

NF-R was supported by a post-doctoral fellowship (Xunta de Galicia Plan I2C 2017-2020, 09.40.561B.444.0) from the government of the autonomous community of Galicia. BY was supported by the Ministry of Science and Higher Education (no. 0409-2016-0022). DLS was supported by the G. E. Hutchinson Chair at the Cary Institute of Ecosystem Studies. AO was supported by the Russian Foundation for Basic Research (no. 17-44-290016). SV was funded by European Investment Funds by FEDER/COMPETE/POCI- Operacional Competitiveness and Internacionalization Programme, under Project POCI-01-0145-FEDER-006958 and National Funds by FCT - Portuguese Foundation for Science and Technology, under the project UID/AGR/ 04033/2013. NF-R is very grateful to the University of OklahomaBiological Survey for providing space to work in the U.S. and especially to Vaughn Lab members. Authors are very grateful to Akimasa Hattori, Allan K. Smith, Andrew Roberts, Daniel Graf, David Stagliano, David T. Zanatta, Dirk Van Damme, Ekaterina Konopleva, Emilie Blevins, Ethan Nedeau, Frankie Thielen, Gregory Cope, Heinrich Vicentini, Hugh Jones, Hülya Şereflişan, Ilya Vikhrev, John Pfeiffer, Karen Mock, Mary Seddon, Katharina Stöckl, Katarzyna Zając, Kengo Ito, Marie Capoulade, Marko Kangas, Michael Lange, Mike Davis, Pirkko-Liisa Luhta, Sarina Jepsen, Somsak Panha, Stephen McMurray, G. Thomas Watters, Wendell R. Haag, and Yoko Inui for their valuable contribution in the initial selection and description of extrinsic and intrinsic factors. We also wish to thank Dr. Amanda Bates, Chase Smith, and two anonymous reviewers for comments on earlier drafts of this manuscript. Any use of trade, firm, or product names is for descriptive purposes only and does not imply endorsement by the U.S. Government.

\section{References}

Abell, R., Allan, J.D., Lehner, B., 2006. Unlocking the potential of protected areas for freshwater. Biol. Conserv. 134, 48-63.

Akiyama, Y., Iwakuma, T., 2007. Survival of glochidial larvae of the freshwater pearl mussel, Margaritifera laevis (Bivalvia: Unionoida), at different temperatures: a comparison between two populations with and without recruitment. Zool. Sci. 24, $890-893$.

Allan, J.D., 2004. Landscape and riverscapes: the influence of land use on river ecosystems. Annu. Rev. Ecol. Evol. Syst. 35, 257-284.

Allen, D.C., Vaughn, C.C., 2009. Burrowing behavior of freshwater mussels in experimentally manipulated communities. J. N. Amer. Benthol. Soc. 28, 93-100.

Araujo, R., Álvarez-Cobelas, M., 2016. Influence of flow diversions on giant freshwater pearl mussel populations in the Ebro River, Spain. Aquat. Conserv. Mar. Freshw. Ecosyst. 26, 1145-1154.

Araujo, R., Buckley, D., Nagel, K., García-Jiménez, R., Machordom, A., 2018. Species boundaries, geographic distribution and evolutionary history of the Western Palaearctic freshwater mussels Unio (Bivalvia, Unionidae). Zool. J. Linnean Soc. 182, 275-299.

Augspurger, T., Keller, A.E., Black, M.C., Cope, W.G., Dwyer, F.J., 2003. Water quality guidance for protection of freshwater mussels (Unionidae) from ammonia exposure. Environ. Toxicol. Chem. 22, 2569-2575.

Baker, A.M., Bartlett, C., Bunn, S.E., Goudkamp, K., Sheldon, F., Hughes, J.M., 2003. Cryptic species and morphological plasticity in long-lived bivalves (Unionoida: Hyriidae) from inland Australia. Mol. Ecol. 12, 2707-2717.

Barnhart, M.C., Haag, W., Roston, W.N., 2008. Adaptations to host infection and larval parasitism in Unionoida. J. N. Am. Benthol. Soc. 27, 370-394.

Benson, J.A., Close, P.G., Stewart, B.A., Lymbery, A., 2017. Upstream recolonization by freshwater mussels (Unionoida: Hyriidae) following installation of a fishway. Aquat. Conserv. Mar. Freshwat. Ecosyst. https://doi.org/10.1002/aqc.2861.

Bielen, A., Bošnjak, I., Sepčić, K., Jaklič, M., Cvitanić, M., Lušić, J., Lajtner, J., Simčić, T., Hudina, S., 2016. Differences in tolerance to anthropogenic stress between invasive and native bivalves. Sci. Total Environ. 543, 449-459.

Bolotov, I.N., Bespalaya, Y.V., Makhrov, A.A., Aspholm, P.E., Aksenov, A.S., Gofarov, M.Y., Dvoryankin, G.A., Usacheva, O.V., Vikhrev, I.V., Sokolova, S.E., Pashinin, A.A. Davydov, A.N., 2012. Influence of historical exploitation and recovery of biological resources on contemporary status of Margaritifera margaritifera L. and Salmo salar L. populations in northwestern Russia. Biol. Bull. Rev. 2, 460-478.

Bolotov, I., Vikhrev, I., Bespalaya, Y., Artamonova, V., Gofarov, M., Kolosova, J., Kondakov, A., Makhrov, A., Frolov, A., Tumpeesuwan, S., Lyubas, A., Romanis, T., Titova, K., 2014. Ecology and conservation of the endangered Indochinese freshwater pearl mussel, Margaritifera laosensis (Lea, 1863) in the Nam Pe and Nam long rivers, northern Laos. Trop. Conserv. Sci. 7, 706-719.

Bolotov, I.N., Kondakov, A.V., Vikhrev, I.V., Aksenova, O.V., Bespalaya, Y.V., Gofarov, M.Y., Kolosova, Y.S., Konopleva, E.S., Spitsyn, V.M., Tanmuangpak, K., Tumpeesuwan, S., 2017a. Ancient river inference explains exceptional oriental freshwater mussel radiations. Sci. Rep. 7, 2135.

Bolotov, I.N., Vikhrev, I.V., Kondakov, A.V., Konopleva, E.S., Gofarov, M.Y., Aksenova, O.V., Tumpeesuwan, S., 2017b. New taxa of freshwater mussels (Unionidae) from a species-rich but overlooked evolutionary hotspot in Southeast Asia. Sci. Rep. 7 , 11573.

British Standards Institution, 2017. Water quality - guidance standard on monitoring freshwater pearl mussel (Margaritifera margaritifera) populations and their environment. In: BS EN 16859:2017. British Standards Institution, London. 
Brown, J.J., Limburg, K.E., Waldman, J.R., Stephenson, K., Glenn, E.P., Juanes, F., Jordaan, A., 2013. Fish and hydropower on the U.S. Atlantic coast: failed fisheries policies from half-way technologies. Conserv. Lett. 6, 280-286.

Bunn, S.E., Thoms, M.C., Hamilton, S.K., Capon, S.J., 2006. Flow variability in dryland rivers: boom, bust and the bits in between. River Res. Appl. 22, 179-186.

Carella, F., Villari, G., Maio, N., DeVico, G., 2016. Disease and disorders of freshwater unionid mussels: a brief overview of recent studies. Front. Physiol. 7, 489.

Carey, C.S., Jones, J.W., Butler, R.S., Hallerman, E.M., 2015. Restoring the endangered oyster mussel (Epioblasma capsaeformis) to the upper Clinch River, Virginia: an evaluation of population restoration techniques. Restor. Ecol. 23, 447-454.

Carter, L.M., Jones, J.W., Berry, L., Burkett, V., Murley, J.F., Obeysekera, J., Schramm, P.J., Wear, D., 2014. Southeast and the Caribbean. In: Melillo, J.M., Richmond, T., Yohe, G.W. (Eds.), Climate Change Impacts in the United States: The Third National Climate Assessment. U.S. Global change research program, Washington, pp. 396-417.

Cope, W.G., Bringolf, R.B., Buchwalter, D.B., Newton, T.J., Ingersoll, C.G., Wang, N., Augspurger, T., Dwye, F.J., Barnhart, M.C., Neves, R.J., Hammer, E., 2008. Differential exposure, duration, and sensitivity of unionoidean bivalve life stages to environmental contaminants. J. N. Am. Benthol. Soc. 27, 451-462.

Council Directive 92/43/EEC of 21 May 1992 on the conservation of natural habitats and of wild fauna and flora. 206. Official Journal, pp. 7-50.

Darrigran, G., Damborenea, C., 2005. A bioinvasion history in South America. Limnoperna fortunei (Dunker, 1857), the golden mussel. Am. Malacol. Bull. 20, 105-112.

Dawson, T.P., Jackson, S.T., House, J.I., Prentice, I.C., Mace, G.M., 2011. Beyond predictions: biodiversity conservation in a changing climate. Science 332, 53-58.

Do, V.T., Le, Q.T., Bogan, A.E., 2018. Freshwater mussels (Bivalvia: Unionoida) of Vietnam: diversity, distribution and conservation status. Freshw. Mollusk Biol. Conserv. 21, 1-18.

Douda, K., Sell, J., Kubíková-Peláková, L., Horký, P., Kaczmarczyk, A., Mioduchowska, M., 2014. Host compatibility as a critical factor in management unit recognition: population-level differences in mussel-fish relationships. J. Appl. Ecol. 51, 1085-1095.

Douda, K., Liu, H.Z., Yu, D., Rouchet, R., Liu, F., Tang, Q.Y., Methling, C., Smith, C., Reichard, M., 2017. The role of local adaptation in shaping fish-mussel coevolution. Freshw. Biol. 62, 1858-1868.

Drummond, A.J., Rambaut, A., Shapiro, B., Pybus, O.G., 2005. Bayesian coalescent inference of past population dynamics from molecular sequences. Mol. Biol. Evol. 22, 1185-1192.

Dudgeon, D., Morton, B., 1983. The population dynamics and sexual strategy of Anodonta woodiana (Bivalvia: Unionacea) in Plover Cove Reservoir, Hong Kong. J. Zool. 201, 161-183.

Dynesius, M., Nilsson, C., 1994. Fragmentation and flow regulation of river systems in the northern third of the world. Science 266, 753-762.

Ferreira-Rodríguez, N., Pardo, I., 2017. The interactive effects of temperature, trophic status, and the presence of an exotic clam on the performance of a native freshwater mussel. Hydrobiologia 797, 171-182.

Ferreira-Rodríguez, N., Fernández, I., Cancela, M.L., Pardo, I., 2018a. Multibiomarker response shows how native and non-native freshwater bivalves differentially cope with heat-wave events. Aquat. Conserv. Mar. Freshwat. Ecosyst. 28, 934-943.

Ferreira-Rodríguez, N., Sousa, R., Pardo, I., 2018b. Negative effects of Corbicula fluminea over native freshwater mussels. Hydrobiologia 810, 85-95.

Fisher, R.A., 1930. The Genetical Theory of Natural Selection. Clarendon Press, Oxford.

Fraser, D.J., Bernatchez, L., 2001. Adaptive evolutionary conservation: towards a unified concept for defining conservation units. Mol. Ecol. 10, 2741-2752.

Froufe, E., Gonçalves, D.V., Teixeira, A., Sousa, R., Varandas, S., Ghamizi, M., Zieritz, A., Lopes-Lima, M., 2016. Who lives where? Molecular and morphometric analyses clarify which Unio species (Unionida, Mollusca) inhabit the southwestern Palearctic region. Org. Divers. Evol. 16, 597-611.

Froufe, E., Lopes-Lima, M., Riccardi, N., Zaccara, S., Vanetti, I., Lajtner, J., Teixeira, A., Varandas, S., Prié, V., Zieritz, A., Sousa, R., Bogan, A.E., 2017. Lifting the curtain on the freshwater mussel diversity of the Italian Peninsula and Croatian Adriatic coast. Biodivers. Conserv. 26, 3255-3274.

Funk, W.C., McKay, J.K., Hohenlohe, P.A., Allendorf, F.W., 2012. Harnessing genomics for delineating conservation units. Trends Ecol. Evol. 27, 489-496.

Gagnon, P.M., Golladay, S.W., Michener, W.K., Freeman, M.C., 2004. Drought responses of freshwater mussels (Unionidae) in coastal plain tributaries of the Flint River basin, Georgia. J. Freshw. Ecol. 19, 667-679.

Gallardo, B., Bogan, A.E., Harun, S., Jainih, L., Lopes-Lima, M., Pizarro, M., Rahim, K.A., Sousa, R., Virdis, S.G.P., Zieritz, A., 2018. Current and future effects of global change on a hotspot's freshwater diversity. Sci. Total Environ. 635, 750-760.

Garvey, J., 2017. Australian aboriginal freshwater shell middens from late Quaternary northwest Victoria: prey choice, economic variability and exploitation. Quat. Int. 427, 85-102.

Geist, J., 2010. Strategies for the conservation of endangered freshwater pearl mussels (Margaritifera margaritifera L.): a synthesis of conservation genetics and ecology. Hydrobiologia 644, 69-88.

Geist, J., Auerswald, K., 2007. Physicochemical stream bed characteristics and recruitment of the freshwater pearl mussel (Margaritifera margaritifera). Freshw. Biol. 52, 2299-2316.

Geist, J., Kuehn, R., 2005. Genetic diversity and differentiation of central European freshwater pearl mussel (Margaritifera margaritifera L.) populations: implications for conservation and management. Mol. Ecol. 14, 425-439.

Geist, J., Porkka, M., Kuehn, R., 2006. The status of host fish populations and fish species richness in European freshwater pearl mussel (Margaritifera margaritifera) streams. Aquat. Conserv. Mar. Freshwat. Ecosyst. 16, 251-266.

Geist, J., Söderberg, H., Karlberg, A., Kuehn, R., 2010. Drainage-independent genetic structure and high genetic diversity of endangered freshwater pearl mussel
(Margaritifera margaritifera) in northern Europe. Conserv. Genet. 11, 1339-1350.

Giam, X., Hadiaty, R.K., Tan, H.H., Parenti, L.R., Wowor, D., Sauri, S., Chong, K.Y., Yeo, D.C., Wilcove, D.S., 2015. Mitigating the impact of oil-palm monoculture on freshwater fishes in Southeast Asia. Conserv. Biol. 29, 1357-1367.

Gillis, P.L., McInnis, R., Salerno, J., de Solla, S.R., Servos, M.R., Leonard, E.M., 2017. Municipal wastewater treatment plant effluent-induced effects on freshwater mussel populations and the role of mussel refugia in recolonizing an extirpated reach. Environ. Pollut. 225, 460-468.

Grabarkiewicz, J.D., Davis, W.S., 2008. An Introduction to Freshwater Mussels and Biological Indicators. USEPA, Office of Environmental Information, Washington.

Graf, D.L., Cummings, K.S., 2011. Freshwater mussel (Mollusca: Bivalvia: Unionoida) richness and endemism in the ecoregions of Africa and Madagascar based on comprehensive museum sampling. Hydrobiologia 678, 17-36.

Graf, D.L., Cummings, K.S., 2018. The freshwater mussels (Unionoida) of the world (and other less consequential bivalves). http://www.mussel-project.net/, Accessed date: 30 March 2018.

Graf, D.L., Jones, H.A., Geneva, A., Pfieffer III, J., Klunzinger, M.W., 2015. Molecular phylogenetic analysis supports a Gondwanan origin of the Hyriidae (Mollusca: Bivalvia: Unionida) and the paraphyly of Australasian taxa. Mol. Phylogenet. Evol. 85, 1-9.

Grizzle, J.M., Brunner, C.J., 2009. Infectious diseases of freshwater mussels and other freshwater bivalve mollusks. Rev. Fish. Sci. 17, 425-467.

Grobler, P.J., Jones, J.W., Johnson, N.A., Beaty, B., Struthers, J., Neves, R.J., Hallerman, E.M., 2006. Patterns of genetic differentiation and conservation of the Slabside Pearlymussel, Lexingtonia dolabelloides (Lea, 1840) in the Tennessee River drainage. J. Molluscan Stud. 72, 65-75.

Haag, W.R., 2012. North American Freshwater Mussels: Natural History, Ecology, and Conservation. Cambridge University Press, Cambridge.

Haag, W.R., Warren Jr., M.L., 2008. Effects of severe drought on freshwater mussel assemblages. Trans. Am. Fish. Soc. 137, 1165-1178.

Hastie, L., Tarr, E., Al-Mousawi, B., Young, M., 2010. Medium-term recruitment patterns in Scottish freshwater pearl mussel Margaritifera margaritifera populations. Endanger. Species Res. 11, 21-33.

van Hattum, B., Korthals, G., Van Straalen, N.M., Govers, H.A.J., Joosse, E.N.G., 1993 Accumulation patterns of trace metals in freshwater isopods in sediment bioassay$\mathrm{s}$-influence of substrate characteristics, temperature and pH. Water Res. 27, 669-684.

Howard, J.K., Cuffey, K.M., 2003. Freshwater mussels in a California North Coast Range river: occurrence, distribution, and controls. J. N. Amer. Benthol. Soc. 22, 63-77.

Hughes, J.M., Baker, A.M., Bartlett, C., Bunn, S.E., Goudkamp, K., Somerville, J., 2004 Past and present patterns of connectivity among populations of four cryptic species of freshwater mussels Velesunio spp. (Hyriidae) in central Australia. Mol. Ecol. 13, 3197-3212.

Inoue, K., Lang, B.K., Berg, D.J., 2015. Past climate change drives current genetic structure of an endangered freshwater mussel species. Mol. Ecol. 24, 1910-1926.

Inoue, K., Hayes, D.M., Harris, J.L., Johnson, N.A., Morrison, C.L., Eackles, M.S., King, T.L., Jones, J.W., Hallerman, E.M., Christian, A.D., Randklev, C.R., 2018. The Pleurobemini (Bivalvia: Unionoida) revisited: DNA barcoding approaches revea multiple undescribed species. Invertebr. Syst. 32, 689-702.

IUCN, 2017. The IUCN Red List of Threatened Species. International Union for Conservation of Nature, Gland, Switzerland. http://www.iucnredlist.org, Accessed date: 5 December 2017.

Jansen, W.A., 1991. Seasonal prevalence, intensity of infestation, and distribution of glochidia of Anodonta grandis simpsoniana Lea on yellow perch, Perca flavescens. Can. J. Zool. 69, 964-972.

Johnson, N.A., McLeod, J.M., Holcomb, J., Rowe, M., Williams, J.D., 2016. Early life history and spatiotemporal changes in distribution of the rediscovered Suwannee moccasinshell Medionidus walkeri (Bivalvia: Unionidae). Endanger. Species Res. 31, 163-175.

Jones, H.A., Byrne, M., 2014. Changes in the distributions of freshwater mussels (Unionoida: Hyriidae) in coastal south-eastern Australia and implications for their conservation status. Aquat. Conserv. Mar. Freshwat. Ecosyst. 24, 203-217.

Jones, J., Hallerman, E., Neves, R., 2006. Genetic management guidelines for conservation and captive propagation of freshwater mussels. J. Shellfish Res. 25, 527-535.

Jones, J.W., Neves, R.J., Hallerman, E.M., 2015. Historical demography of freshwater mussels (Bivalvia: Unionidae): genetic evidence for population expansion and contraction during the late Pleistocene and Holocene. Biol. J. Linn. Soc. 114, 376-397.

Kelly, C.B., Watters, G.T., 2010. Distribution and prevalence of glochidia-infested wildcaught fishes at a Muskingum River site in southeastern Ohio. J. Freshw. Ecol. 25, 119-126.

Kelner, D.E., Sietman, B.E., 2000. Relic populations of the ebony shell, Fusconaia ebena (Bivalvia: Unionidae) in the upper Mississippi River drainage. J. Freshw. Ecol. 15, 371-377.

Kleinhenz, L.S., Trenfield, M.A., Mooney, T.J., Humphrey, C.L., van Dam, R.A., Nugegoda, D., Harford, A.J., 2018. Acute ammonia toxicity to the larvae (glochidia) of the tropical Australian freshwater mussel Velesunio spp. using a modified toxicity test protocol. Environ. Toxicol. Chem. 37, 2175-2187.

Klunzinger, M.W., Beatty, S.J., Morgan, D.L., Thomson, G.J., Lymbery, A.J., 2012 Glochidia ecology in wild fish populations and laboratory determination of competent host fishes for an endemic freshwater mussel of south-western Australia. Aust. J. Zool. 60, 26-36.

Klunzinger, M.W., Beatty, S.J., Morgan, D.L., Lymbery, A.J., Haag, W.R., 2014. Age and growth in the Australian freshwater mussel, Westralunio carteri, with an evaluation of the fluorochrome calcein for validating the assumption of annulus formation. Freshw. Sci. 33, 1127-1135.

Klunzinger, M.W., Beatty, S.J., Morgan, D.L., Pinder, A.M., Lymbery, A.J., 2015. Range 
decline and conservation status of Westralunio carteri Iredale, 1934 (Bivalvia: Hyriidae) from south-western Australia. Aust. J. Zool. 63, 127-135.

Koneva, A.Y., 2013. Genetic estimation of snail Lymnaea stagnalis populations from regions with different anthropogenic load as a first step in genetic monitoring. Russ. J. Genet. 5, 361-370.

Kundzewicz, Z.W., Mata, L.J., Arnell, N.W., Döll, P., Jimenez, B., Miller, K., Oki, T., Șen, Z., Shiklomanov, I., 2008. The implications of projected climate change for freshwater resources and their management. Hydrol. Sci. J. 54, 3-10.

Linehan, K., 2007. Evaluation of Knowledge, Attitudes, and Opinions of Town and County Leaders, Residents, and the Environmental Community of Endangered Species and Aquatic Conservation in Tazewell County, Virginia. Virginia Polytechnic Institute and State University, Blacksburg, VA (MSc thesis).

Lockwood, J.L., Hoopes, M.F., Marchetti, M.P., 2013. Invasion Ecology, 2nd ed. WileyBlackwell, West Sussex, UK.

Lois, S., Ondina, P., Outeiro, A., Amaro, R., San Miguel, E., 2014. The north-west of the Iberian Peninsula is crucial for conservation of Margaritifera margaritifera (L.) in Europe. Aquat. Conserv. Mar. Freshwat. Ecosyst. 24, 35-47.

Lopes-Lima, M., Teixeira, A., Froufe, E., Lopes, A., Varandas, S., Sousa, R., 2014. Biology and conservation of freshwater bivalves: past, present and future perspectives. Hydrobiologia 735, 1-13.

Lopes-Lima, M., Sousa, R., Geist, J., Aldridge, D.C., Araujo, R., Bergengren, J., Bespalaya, Y., Bódis, E., Burlakova, L., van Damme, D., Douda, K., Froufe, E., Georgiev, D., Gumpinger, C., Karatayev, A., Kebapci, U., Killeen, I., Lajtner, J., Larsen, B., Lauceri, R., Legakis, A., Lois, S., Lundberg, S., Moorkens, E., Motte, G., Nagel, K.-O., Ondina, P., Outeiro, A., Paunovic, M., Prié, V., von Proschwitz, T., Riccardi, N., Rudzīte, M., Rudzītis, M., Scheder, C., Seddon, M., Şereflişan, H., Simic, V., Sokolova, S., Stoeckl, K., Taskinen, J., Teixeira, A., Thielen, F., Trichkova, T., Varandas, S., Vicentini, H. Zajac, K., Zajac, T., Zogaris, S., 2017. Conservation status of freshwater mussels in Europe: state of the art and future challenges. Biol. Rev. 92, 572-607.

Lopes-Lima, M., Burlakova, L.E., Karatayev, A.Y., Mehler, K., Seddon, M., Sousa, R., 2018. Conservation of freshwater bivalves at the global scale: diversity, threats and research needs. Hydrobiologia 810, 1-14.

Lucy, F.E., Burlakova, L.E., Karatayev, A.Y., Mastitsky, S.E., Zanatta, D.T., 2014. Zebra mussel impacts on unionids: A synthesis of trends in North America and Europe. In: Nalepa, T.F., Schloesser, D.W. (Eds.), Quagga and Zebra Mussels: Biology, Impacts, and Control. CRC Press, Boca Raton, FL, pp. 623-646.

Makhrov, A., Bespalaya, J., Bolotov, I., Vikhrev, I., Gofarov, M., Alekseeva, Ya, Zotin, A., 2014. Historical geography of pearl harvesting and current status of populations of the freshwater pearl mussel Margaritifera margaritifera (L.) in west part of northern European Russia. Hydrobiologia 735, 149-159.

McMurray, S.E., Roe, K.J., 2017. Perspectives on the controlled propagation, augmentation, and reintroduction of freshwater mussels (Mollusca: Bivalvia: Unionoida). Ecol. Stud. 20, 1-12.

Michalak, P., Kang, L., Ciparis, S., Henley, W., Jones, J., Phipps, A., Hallerman, E., 2017. Freshwater mussels exposed to arsenic and sulfate show contrasting patterns of gene expression. In: Ray, S. (Ed.), Organismal and Molecular Malacology. InTech Publishing, Rijeka, Croatia, pp. 99-117.

Modesto, V., Ilarri, M., Souza, A.T., Lopes-Lima, M., Douda, K., Clavero, M., Sousa, R., 2018. Fish and mussels: importance of fish for freshwater mussel conservation. Fish 19, 244-259.

Morrison III, W.R., Lohr, J.L., Duchen, P., Wilches, R., Trujillo, D., Mair, M., Renner, S.S., 2009. The impact of taxonomic change on conservation: does it kill, can it save, or is it just irrelevant? Biol. Conserv. 142, 3201-3206.

Mynsberge, A.R., Strager, M.P., Strager, J.M., Mazik, P.M., 2009. Developing predictive models for freshwater mussels (Mollusca: Unionidae) in the Appalachians: limitations and directions for future research. Ecoscience 16, 387-398.

Naimo, T.J., 1995. A review of the effects of heavy metals on freshwater mussels. Ecotoxicology 4, 341-362.

Nakano, M., 2017. The effect of paddy drainage water on the survival and growth of unionoid mussels. Agric. Ecosyst. Environ. 247, 189-194.

Newton, T.J., Woolnough, D.A., Strayer, D.L., 2008. Using landscape ecology to understand and manage freshwater mussel populations. J. N. Am. Benthol. Soc. 27, 424-439.

Nishio, M., Edo, K., Yamazaki, Y., 2017. Paddy management for potential conservation of endangered Itasenpara bitterling via zooplankton abundance. Agric. Ecosyst. Environ. 247, 166-171.

Nunney, L., Campbell, K.A., 1993. Assessing minimum viable population size: demography meets population genetics. Trends Ecol. Evol. 8, 234-239.

Österling, M.E., Arvidsson, B.L., Greenberg, L.A., 2010. Habitat degradation and the decline of the threatened mussel Margaritifera margaritifera: influence of turbidity and sedimentation on the mussel and its host. J. Appl. Ecol. 47, 759-768.

Outeiro, A., Ondina, P., Fernández, C., Amaro, R., San Miguel, E., 2008. Population density and age structure of the freshwater pearl mussel, Margaritifera margaritifera, in two Iberian rivers. Freshw. Biol. 53, 485-496.

Pandolfo, T.J., Cope, W.G., Arellano, C., Bringolf, R.B., Barnhart, M.C., Hammer, E., 2010. Upper thermal tolerances of early life stages of freshwater mussels. J. N. Am. Benthol. Soc. 29, 959-969.

Patterson, M.A., Mair, R.A., Eckert, N.L., Gatenby, C.M., Brady, T., Jones, J.W., Simmons, B.R., Devers, J.L., 2018. Freshwater Mussel Propagation for Restoration. Cambridge University Press, Cambridge.

Pieri, A.M., Inoue, K., Johnson, N.A., Smith, C.H., Harris, J.L., Robertson, C., Randklev, C.R., 2018. Molecular and morphometric analyses reveal cryptic diversity within freshwater mussels (Bivalvia: Unionidae) of the western gulf coastal drainages of the USA. Biol. J. Linn. Soc. 124, 261-277.

Popejoy, T., Randklev, C.R., Neeson, T.M., Vaughn, C.C., 2018. Prioritizing sites for conservation based on similarity to historical baselines and feasibility of protection.
Conserv. Biol. 32, 1118-1127.

Prein, A.F., Rasmussen, R.M., Ikeda, K., Liu, C., Clark, M.P., Holland, G.J., 2016. The future intensification of hourly precipitation extremes. Nat. Clim. Chang. 7, 48-52.

Prié, V., Puillandre, N., 2014. Molecular phylogeny, taxonomy, and distribution of French Unio species (Bivalvia, Unionidae). Hydrobiologia 735, 95-110.

Prié, V., Molina, Q., Gamboa, B., 2014. French naiad (Bivalvia: Margaritiferidae, Unionidae) species distribution models: prediction maps as tools for conservation. Hydrobiologia 735, 81-94.

Prié, V., Soler, J., Araujo, R., Cucherat, X., Philippe, L., Patry, N., Benjamin Adam, B., Legrand, N., Jugé, P., Richard, N., Wantzen, K.M., 2018. Challenging exploration of troubled waters: a decade of surveys of the giant freshwater pearl mussel Margaritifera auricularia in Europe. Hydrobiologia 810, 157-175.

Pringle, C.M., Freeman, M.C., Freeman, B.J., 2000. Regional effects of hydrologic alterations on riverine macrobiota in the new world: tropical-temperate comparisons. Bioscience 50, 807-823.

Randklev, C.R., Miller, T., Hart, M., Morton, J., Johnson, N.A., Skow, K., Inoue, K., Tsakiris, E.T., Oetker, S., Smith, R., Robertson, C., Lopez, R., 2018. A semi-arid river in distress: contributing factors and recovery solutions for three imperiled freshwater mussels (family Unionidae) endemic to the Rio Grande basin in North America. Sci. Total Environ. 631-632, 733-744.

Reid, N., Keys, A., Preston, J.S., Moorkens, E., Roberts, D., Wilson, C.D., 2012. Conservation status and reproduction of the critically endangered freshwater pearl mussel (Margaritifera margaritifera) in Northern Ireland. Aquat. Conserv. Mar. Freshwat. Ecosyst. 23, 571-581.

Saha, S., Layzer, J.B., 2008. Evaluation of a nonlethal technique for determining sex of freshwater mussels. J. N. Am. Benthol. Soc. 27, 84-89.

Salonen, J.K., Taskinen, J., 2017. Electrofishing as a new method to search for unknown populations of the endangered freshwater pearl mussel Margaritifera margaritifera. Aquat. Conserv. Mar. Freshwat. Ecosyst. 27, 115-127.

Salonen, J.K., Luhta, P.-L., Moilanen, E., Oulasvirta, P., Turunen, J., Taskinen, J., 2017. Atlantic salmon (Salmo salar) and brown trout (Salmo trutta) differ in their suitability as a host for the endangered freshwater pearl mussel (Margaritifera margaritifera) in northern Fennoscandian rivers. Freshw. Biol. 62, 1346-1358.

Sansom, B.J., Sassoubre, L.M., 2017. Environmental DNA (eDNA) shedding and decay rates to model freshwater mussel eDNA transport in a river. Environ. Sci. Technol. 51, 14244-14253.

Santos, R.M.B., Fernandes, L.F.S., Varandas, S.G.P., Pereira, M.G., Sousa, R., Teixeira, A., Lopes-Lima, M., Cortes, R.M.V., Pacheco, F.A.L., 2015. Impacts of climate change and land-use scenarios on Margaritifera margaritifera, an environmental indicator and endangered species. Sci. Total Environ. 511, 477-488.

Schwartz, M.K., Luikart, G., Waples, R.S., 2007. Genetic monitoring as a promising tool for conservation and management. Trends Ecol. Evol. 22, 25-34.

Sheldon, F., 2017. Variable plasticity in shell morphology of some Australian freshwater mussels (Unionoida, Hyriidae). Trans. R. Soc. S. Aust. 141, 193-208.

Smith, D.G., 1985. Recent range expansion of the freshwater mussel Anodonta implicata and its relationship to clupeid fish restoration in the Connecticut River system. Freshw. Invertebr. Biol. 4, 105-108.

Smith, C.H., Johnson, N.A., Pfeiffer, J.M., Gangloff, M.M., 2018. Molecular and morphological data reveal non-monophyly and speciation in imperiled freshwater mussels (Anodontoides and Strophitus). Mol. Phylogenet. Evol. 119, 50-62.

Sousa, R., Novais, A., Costa, R., Strayer, D., 2014. Invasive bivalves in fresh waters: im pacts from individuals to ecosystems and possible control strategies. Hydrobiologia 735, 233-251.

Sousa, R., Ferreira, A., Carvalho, F., Lopes-Lima, M., Varandas, S., Teixeira, A., 2018. Dieoffs of the endangered pearl mussel Margaritifera margaritifera during an extreme drought. Aquat. Conserv. Mar. Freshwat. Ecosyst. 28, 1244-1248.

Stansbery, D.H., 1970. Eastern freshwater mollusks. I. The Mississippi and St. Lawrence River systems. In: American Malacological Union Symposium on Rare and Endangered Mollusks. Malacologia 10. pp. 9-22.

Stansbery, D.H., 1971. Rare and endangered freshwater mollusks in eastern United States. In: Jorgensen, S.E., Sharp, R.E. (Eds.), Proceedings of a Symposium on Rare and Endangered Mollusks (naiads) of the U.S. U.S. Fish Wildlife Service, Twin Cities, MN, pp. 5-18.

Steuer, J.J., Newton, T.J., Zigler, S.J., 2008. Use of complex hydraulic variables to predict the distribution and density of unionids in a side channel of the Upper Mississippi River. Hydrobiologia 610, 67-82.

Stodola, K.W., Stodola, A.P., Tiemann, J.S., 2017. Survival of translocated Clubshell and Northern Riffleshell in Illinois. Freshw. Mollusk Biol. Conserv. 20, 89-102.

Stoeckl, K., Taeubert, J.E., Geist, J., 2015. Fish species composition and host fish density in streams of the thick-shelled river mussel (Unio crassus) - implications for conservation. Aquat. Conserv. Mar. Freshwat. Ecosyst. 25, 276-287.

Strayer, D.L., 1999. Use of flow refuges by unionid mussels in rivers. J. N. Am. Benthol. Soc. $18,468-476$.

Strayer, D.L., 2008. Freshwater Mussel Ecology: A Multifactor Approach to Distribution and Abundance. University of California Press, Berkeley.

Strayer, D.L., 2017. What are freshwater mussels worth? Freshw. Mollusk Biol. Conserv. 20, 103-113.

Strayer, D.L., Malcom, H.M., 2012. Causes of recruitment failure in freshwater mussel populations in southeastern New York. Ecol. Appl. 22, 1780-1790.

Strayer, D.L., Downing, J.A., Haag, W.R., King, T.L., Layzer, J.B., Newton, T.J., Nichols, S.J., 2004. Changing perspectives on pearly mussels, North Americas most imperiled animals. Bioscience 54, 429-439.

Taeubert, J.-E., El-Nobi, G., Geist, J., 2014. Effects of water temperature on the larval parasitic stage of the thick-shelled river mussel (Unio crassus). Aquat. Conserv. Mar. Freshwat. Ecosyst. 24, 231-237.

Taniguchi, Y., Fausch, K.D., Nakano, S., 2002. Size-structured interactions between native 
and introduced species: can intraguild predation facilitate invasion by stream salmonids? Biol. Invasions 4, 223-233.

Taskinen, J., Valtonen, E.T., 1995. Age-, size- and sex-specific infection of Anodonta piscinalis (Bivalvia, Unionidae) with Rhipidocotyle fennica (Digenea, Bucephalidae) and its influence on host reproduction. Can. J. Zool. 73, 887-897.

Taskinen, J., Berg, P., Saarinen-Valta, M., Välilä, S., Mäenpää, E., Myllynen, K., Pakkala, J., 2011. Effect of $\mathrm{pH}$, iron and aluminum on survival of early life history stages of the endangered freshwater pearl mussel, Margaritifera margaritifera. Toxicol. Environ. Chem. 93, 1764-1777.

Terui, A., Miyazaki, Y., Yoshioka, A., Kaifu, K., Matsuzaki, S.I.S., Washitani, I., 2014. Asymmetric dispersal structures a riverine metapopulation of the freshwater pearl mussel Margaritifera laevis. Ecol. Evol. 4, 3004-3014.

Tiemann, J.S., Gillette, D.P., Wildhaber, M.L., Edds, D.R., 2004. Effects of lowhead dams on riffle-dwelling fishes and macroinvertebrates in a Midwestern river. Trans. Am. Fish. Soc. 133, 705-717.

Tyrrell, M., Hornbach, D.J., 1998. Selective predation by muskrats on freshwater mussels in two Minnesota rivers. J. N. Am. Benthol. Soc. 17, 301-310.

Vandermeer, J.H., Goldberg, D.E., 2003. Population Ecology: First Principles. Princeton University Press, Princeton, NJ.

Vaughn, C.C., 2012. Life history traits and abundance can predict local colonisation and extinction rates of freshwater mussels. Freshw. Biol. 57, 982-992.

Vaughn, C.C., 2018. Ecosystem services provided by freshwater mussels. Hydrobiologia $810,15-27$.

Vaughn, C.C., Nichols, S.J., Spooner, D.E., 2008. Community and food web ecology of freshwater mussels. J. N. Amer. Benthol. Soc. 27, 409-423.

Vaughn, C.C., Atkinson, C.L., Julian, J.P., 2015. Drought-induced changes in flow regimes lead to long-term losses in mussel-provided ecosystem services. Ecol. Evol. 5, 1291-1305.

Wächtler, K., Dreher-Mansur, M.C., Richter, T., 2001. Larval types and early post larval biology in naiads (Unionoida). In: Bauer, G., Wächtler, K. (Eds.), Ecology and Evolution of Freshwater Mussels Unionoida. Springer-Verlag, Berlin, pp. 93-125.

Walker, K.F., Jones, H.A., Klunzinger, M.W., 2014. Bivalves in a bottleneck: taxonomy, phylogeography and conservation of freshwater mussels (Bivalvia: Unionoida) in Australasia. Hydrobiologia 735, 61-79.

Walters, A.D., Ford, D., Chong, E.T., Williams, M.G., Ford, N.B., Williams, L.R., Banta, J.A., 2017. High-resolution ecological niche modelling of threatened freshwater mussels in east Texas, USA. Aquat. Conserv. Mar. Freshw. Ecosyst. 27, 1251-1260.

Wang, N., Ivey, C.D., Ingersoll, C.G., Brumbaugh, W.G., Alvarez, D., Hammer, E.J., Bauer, C.R., Augspurger, T., Raimondo, S., Barnhart, M.C., 2017. Acute sensitivity of a broad range of freshwater mussels to chemicals with different modes of toxic action.
Environ. Toxicol. Chem. 36, 786-796.

Watters, G.T., 1996. Small dams as barriers to freshwater mussels (Bivalvia, Unionidae) and their hosts. Biol. Conserv. 75, 79-85.

Wicklow, B.J., Cormier, T.A., Bishop, J.B., Devers, J., von Oettingen, S., 2017. The conservation status of the brook floater mussel, Alasmidonta varicosa, in the United States: trends in distribution, occurrence, and condition of populations. https:// rcngrants.org/content/conservation-status-brook-floater-mussel-alasmidontavaricosa-northeastern-united-states, Accessed date: 4 April 2018.

Williams, S.E., Shoo, L.P., Isaac, J.L., Hoffmann, A.A., Langham, G., 2008. Towards an integrated framework for assessing the vulnerability of species to climate change. PLoS Biol. 6, e325.

Williams, J.D., Bogan, A.E., Butler, R.S., Cummings, K.S., Garner, J.T., Harris, J.L., Johnson, N.A., Watters, G.T., 2017. A revised list of the freshwater mussels (Mollusca: Bivalvia: Unionida) of the United States and Canada. Freshw. Mollusk Biol. Conserv. 20, 33-58.

Winemiller, K.O., McIntyre, P.B., Castello, L., Fluet-Chouinard, E., Giarrizzo, T., Nam, S., Baird, I.G., Darwall, W., Lujan, N.K., Harrison, I., Stiassny, M.L.J., Silvano, R.A.M., Fitzgerald, D.B., Pelicice, F.M., Agostinho, A.A., Gomes, L.C., Albert, J.S., Baran, E., Petrere Jr., M., Zarfl, C., Mulligan, M., Sullivan, J.P., Arantes, C.C., Sousa, L.M., Koning, A.A., Hoeinghaus, D.J., Sabaj, M., Lundberg, J.G., Armbruster, J., Thieme, M.L., Petry, P., Zuanon, J., Torrente Vilara, G., Snoeks, J., Ou, C., Rainboth, W., Pavanelli, C.S., Akama, A., van Soesbergen, A., Sáenz, L., 2016. Balancing hydropower and biodiversity in the Amazon, Congo and Mekong. Science 351, 128-129.

Zając, K., 2014. Size-dependent predation by the otter Lutra lutra on swan mussels Anodonta cygnea (Linnaeus, 1758) - observations and radiotelemetry experiment. J. Conchol. 41, 559-563.

Zając, K., Florek, J., Zając, T., Adamski, P., Bielański, W., Ćmiel, A., Klich, M., Lipińska, A.M., 2018. On the reintroduction of the endangered thick-shelled river mussel Unio crassus: the importance of the river's longitudinal profile. Sci. Total Environ. 624, 273-282.

Zanatta, D.T., Harris, A.T., 2013. Phylogeography and genetic variability of the freshwater mussels (Bivalvia: Unionidae) ellipse, Venustaconcha ellipsiformis (Conrad 1836), and bleeding tooth, V. pleasii (marsh 1891). Am. Malacol. Bull. 31, 267-279.

Zieritz, A., Hoffman, J.I., Amos, H., Aldridge, D.C., 2010. Phenotypic plasticity and genetic isolation-by-distance in the freshwater mussel Unio pictorum (Mollusca: Unionidae). Evol. Ecol. 24, 923-938.

Zieritz, A., Bogan, A.E., Rahim, K.A., Sousa, R., Jainih, L., Harun, S., Razak, N.F.A., Gallardo, B., McGowan, S., Hassan, R., Lopes-Lima, M., 2018. Changes and drivers of freshwater mussel diversity and distribution in northern Borneo. Biol. Conserv. 219, 126-137. 